\title{
Gesinsmoord in Suid-Afrika
}

\author{
H Conradie \\ Universiteit van Suid-Afrika
}

\begin{abstract}
Family murders in South Africa

The goal of research into 'Family Murders in South Africa' was to determine the views of members of the Criminological Society of Southern Africa concerning family murder. The hypothesis was that these informed persons would agree with the statements made by academics in the press regarding this phenomenon. The research substantiated the hypothesis. The dominant psychological causes were listed as feelings of rejection, stress, emotional burn-out and pathological possessiveness. The sociological causes were listed as alienation between spouses and misuse of alcohol. The warning signs included previous suicide attempts, unsuccessful attempts to restore broken marriages, unemployment, physical assault, fathers retreating from the family and neighbours and obsessive handling of dangerous weapons. Based on the findings of the research, a list identifying causes, warning signs, explanations, and methods of prevention was drawn up.
\end{abstract}

\section{INLEIDING}

De Jongh Van Arkel (1988:11) sê meer as 200 mense het in 'n vyfjaartydperk in die RSA weens gesinsmoorde gesterf. Dit verteenwoordig 'n gemiddelde van 40 individue per jaar. Op sigself geneem is dit natuurlik nie 'n fenomenale syfer nie. Dit verminder egter ook nie die verslaenheid waarmee mense daarop reageer wanneer 'n gesinsmoord wel voorkom nie. Gesinslede het mekaar tog lief en dit veronderstel versorging en ondersteuning van mekaar - uitwissing funksioneer nie in die normale denkraamwerk wanneer die gesin ter sprake is nie. Tog kom dit voor. 
Erasmus (1988:8) definieer gesinsmoord as die eliminering of poging tot eliminering deur een lid van 'n gesin van die ander lede van die gesin wat daarna selfmoord pleeg. In hierdie artikel word aandag gegee aan die oorsake, waarskuwingstekens, verklarings en voorkoming van hierdie verskynsel.

\section{DIE PROBLEMA ITEK}

Bachar (1985:6) sê seks, geld, drank en apartheid is verantwoordelik vir die toenemende aantal blanke Suid-Afrikaners wat hul gesinne uitwis en daarna selfmoord pleeg. Olivier (1989:18) het met haar navorsing onder Blankes, Indiërs en Kleurlinge bevind dat 1,4 persent van die respondente reeds die gedagte gehad het om gesinsmoord te pleeg, terwyl die syfer by Swartes 3,4 persent was. In November 1984 was die syfer vir gesinsmoorde vir dié jaar reeds 55 (Van Zyl 1984:3). Hierdie syfers verteenwoordig 15 individuele gesinne wat uitgewis is. Net in Transvaal alleen het sowat 36 volwassenes en 16 kinders in 1988 gesterf, en sowat 8 is in 22 voorvalle gewond.

Benewens die feit dat dit 'n verskynsel met baie fasette is, waarin die misdadiger en die slagoffer nie toeganklik is vir navorsing nie, word soveel verskillende uitsprake daaroor gemaak dat dit moeilik is om die standpunte selfs sinvol te sorteer. Hierbenewens is dit moeilik om die legitimiteit van die selfrapporteringstudies soos dié van Olivier te kontrolleer en om die impak wat die verlies van 'n hele gesin op 'n gemeenskap het, wetenskaplik te verreken. Nietemin is dit juis onder andere hierdie problematiek wat my poging tot navorsing in die veld gestimuleer het.

Oorsake, waarskuwingstekens en verklarings gee insig in die aard van die verskynsel en in die hantering van (minstens) dreigimente tot gesinsuitwissing. Dit kan help met voorkomingsaksies. Derhalwe word die klem vir die doel van hierdie artikel beperk tot hierdie aspekte.

\section{HIPOTESE EN NAVORSINGMETODOLOGIE}

Die hipotese vir hierdie ondersoek was dat kriminologies-ingeligtes saamstem oor die oorsake, waarskuwingstekens, verklarings en voorkoming van gesinsmoorde, afgesien van die beroepsareas waarin hulle werksaam is.

Ten einde die hipotese te toets, is literatuurstudie en 'n empiriese opname onder kriminologies-ingeligtes onderneem. Omdat daar slegs op die Suid-Afrikaanse situasie gekonsentreer is, het net toepaslike binnelandse literatuur onder die loep gekom. Die literatuur wat opgespoor kon word, het hoofsaaklik bestaan uit persverklarings wat daaroor in koerante en populêre tydskrifte gemaak is, soos uit die bibliografie afgelei kan word. Slegs 'n enkele wetenskaplike ondersoek soos dié van Olivier kon opgespoor word. 
Verder is toestemming van die Raad van KRIMSA (Kriminologiese Vereniging van Suidelike Afrika) verkry om die persone wat gedurende 1989-1990 lede van die Vereniging was, te nader met 'n vraelys. Vierhonderd en vyftig vraelyste is gedurende Junie 1990 uitgestuur (die volledige adreslys is gebruik). Hiervan is 298 (66\%) binne die verloop van 6 weke terug ontvang. Die empiriese data waarna verwys word, kom uit hierdie response. Gebaseer op die literatuurstudie is 'n klompie stellings gegenereer wat in die vraelys opgeneem is. Ter wille van die lengte van die vraelys is slegs enkele van die baie stellings (wat almal gegee word) wat in die literatuur opgespoor is oor elk van die oorsake, waarskuwingstekens, verklarings en voorkoming, in die vraelys geakkomodeer.

Die ondersoekgroep het uit $48,3 \%$ manlike en $51,3 \%$ vroulike respondente bestaan. Enkeles het nie hulle geslag aangedui nie. Die Blankes was $71,8 \%$, die Swartes $19,5 \%$, die Asiërs $7,4 \%$ en die Kleurlinge 1,0\% van die respondente. Wat woonplek betref was $91,9 \%$ van die respondente in Suid-Afrika self woonagtig, $3 \%$ het in Bophuthatswana gewoon, $1,7 \%$ in Ciskei, $2 \%$ in Transkei, $0,7 \%$ in Venda en $0,3 \%$ in Namibië tydens die navorsing. Die meerderheid van die respondente $(39,9 \%)$ kom uit stedelike gebiede. Die res $(32,6 \%$ en $27,2 \%)$ kom uit voorstedelike en plattelandse gebiede respektiewelik.

Omdat die beroepsareas verderaan gebruik sal word in die ontledings wat volg, word dit tabellaries voorgestel in tabel 1. Die frekwensies word telkens in hakies weergegee.

Tabel 1. Die beroepsareas van die respondente

\begin{tabular}{|l|l|l|l|l|c|c|}
\hline $\begin{array}{l}\text { Privaat } \\
\text { sektor }\end{array}$ & $\begin{array}{l}\text { Openbare } \\
\text { sektor }\end{array}$ & Akademie & Polisie & $\begin{array}{l}\text { Gevangenis- } \\
\text { diens }\end{array}$ & $\begin{array}{l}\text { Gesondheids- } \\
\text { dienste }\end{array}$ & Totaal \\
\hline $\begin{array}{l}29,5 \% \\
(82)\end{array}$ & $\begin{array}{l}15,8 \% \\
(44)\end{array}$ & $\begin{array}{l}20,1 \% \\
(56)\end{array}$ & $\begin{array}{l}24,8 \% \\
(69)\end{array}$ & $\begin{array}{l}4,3 \% \\
(12)\end{array}$ & $\begin{array}{l}5 \% \\
(14)\end{array}$ & $277^{*}$ \\
\hline
\end{tabular}

* Een-en-twintig respondente het nie hul beroepsareas aangedui nie.

Vir ontledingsdoeleindes is proefpersone uit die privaatsektor, die openbare sektor, asook die akademici en polisie geneem, omdat hulle duidelik die sterkste verteenwoordig is.

\section{DIE OORSAKE}

Uit die aard van die saak verskil die redes waarom mense gesinsmoorde pleeg (Hart 1985:23). Daarom word 'n veeltal redes as veroorsakende faktore vir gesinsmoorde genoem. Wanneer dit gerangskik word, kan dit gereduseer word tot drie aspekte 
(Van Zyl 1984:3; Pienaar 1978:16-18; Thomas 1988:6; Du Toit 1988:15; Bloomberg 1988:4; Francisco-la Grange 1985:23), naamlik:

Tabel 2. Literatuurstudie se hys van oorsake

\begin{tabular}{|l|l|l|}
\hline Ekonomies & \multicolumn{1}{|c|}{ Sielkundig } & \multicolumn{1}{|c|}{ Sosiologies } \\
\hline werkloosheid & verwerping; depressie & verlating \\
problemle & spanningonderdrukking & ongelukkige huwelik \\
& swak selfbeeld & vervreemding tussen \\
& man en vrou \\
& onstabie wanhoop & oppervlakkige \\
& emosionele uitbranding & mensliewendheid \\
& aggressie; 'fenced in' & seksuele jaloesie \\
& 'eleurstellings oor eie & culture lag' \\
& mislukkings; frustrasie & genadedoodleme \\
& psigotiese bedruktheid & swak gesins- \\
& emosionele opwelling & verhoudinge \\
& selfmoorddreigimente & \\
& beslissingsonbevoegdheid & \\
& apatie & \\
\hline
\end{tabular}

Olivier (1988:117-118) identifiseer verskeie oorsake (wat ook in die bogenoemde lys ingepas kan word) vir die verskynsel, en klassifisieer dit soos volg: Die intrapsigiese faktore sluit in aggressievlak, algemene uitputting, gebrek aan vertroue in ander, en hoë spanningsvlak. Die sosiologiese faktore wat sy onderskei sluit in werkloosheid, vrees vir afdanking, finansiële probleme, huweliksprobleme, gebrek aan ondersteuningstelsels en bekommernis oor kinders.

Ten opsigte van die geselekteerdes van hierdie aspekte wat aan die lede van KRIMSA voorgele is, het dit reaksies soos in tabel 3 uiteengesit word, na vore gebring. Uit hierdie tabel kan duidelik afgelei word dat die respondente die oorsake wat in die literatuur aangegee word, sterk ondersteun. Die uitsondering is duidelik oppervlakkige liefde. Die respondente is glad nie oortuig dat dit as 'n oorsaak vir gesinsmoorde aangevoer kan word nie. Die aansienlik laer reaksie van die respondente rakende die rol van sterk drank by die veroorsaking van gesinsmoorde, is verrassend. 
Tabel 3. Respondente oor die oorsake

\begin{tabular}{|l|l|l|l|l|}
\hline Oorsake & $\begin{array}{c}\text { Privaat } \\
\text { sektor }\end{array}$ & $\begin{array}{l}\text { Openbare } \\
\text { sektor }\end{array}$ & Akademici & Polisie \\
\hline Gevoelens van verwerping & $82 \%(67)$ & $79 \%(34)$ & $73 \%(41)$ & $84 \%(58)$ \\
\hline Erge stress & $95 \%(75)$ & $95 \%(41)$ & $91 \%(51)$ & $90 \%(62)$ \\
\hline Emosionele uitbranding & $89 \%(73)$ & $93 \%(40)$ & $88 \%(49)$ & $84 \%(58)$ \\
\hline Patologiese besitlikheid & $73 \%(60)$ & $82 \%(36)$ & $80 \%(45)$ & $81 \%(56)$ \\
\hline Vervreemding: man en vrou & $73 \%(60)$ & $84 \%(37)$ & $73 \%(40)$ & $87 \%(59)$ \\
\hline Misbruik van sterk drank & $64 \%(52)$ & $59 \%(26)$ & $61 \%(34)$ & $68 \%(47)$ \\
\hline Oppervlakkige liefde/apatie & $32 \%(26)$ & $30 \%(13)$ & $25 \%(14)$ & $33 \%(23)$ \\
\hline
\end{tabular}

\section{DIE WAARSKUWINGSTEKENS}

Tot op sekere hoogte hou die waarskuwingstekens wat in die literatuur gelys word, ook verband met die voorafgaande. Die waarskuwingstekens is die volgende (Van Zyl 1984:3):

Tabel 4. Literatuurstudie se lys van waarskuwingstekens

\begin{tabular}{|l|l|}
\hline \multicolumn{1}{|c|}{ Psigologies } & \multicolumn{1}{c|}{ Sosiologies } \\
\hline aggressie; slapeloosheid; & verloor belangstelling in \\
innerlik onrustig; & huweliksverhouding; probeer \\
verseg om onbelangrik & dit onsuksesvol herstel; \\
te bly; & drink te veel; slaan die \\
geskiedenis van vorige & huweliksmaat en dreig haar \\
selfmoordpogings; & met die dood; onttrek van \\
altyd emosioneel kwesbaar & gesinslede en bure \\
\hline
\end{tabular}

Die psigiese aspekte kan opsommend onder drukspanning geklassifiseer word en die sosiale aspekte weer onder geborgenheidsgebrek. Dit is opmerklik dat die ekonomiese modaliteit nie figureer in die kader van die waarskuwingstekens nie.

Die respondente het hul menings soos volg oor die toepaslike waarskuwingstekens uitgespreek (tabel 5): 
Tabel 5. Respondente oor waarskuwingstekens

\begin{tabular}{|l|l|l|l|l|}
\hline \multicolumn{1}{|c|}{$\begin{array}{c}\text { Waarskuwings- } \\
\text { tekens }\end{array}$} & $\begin{array}{l}\text { Privaat } \\
\text { sektor }\end{array}$ & $\begin{array}{l}\text { Openbare } \\
\text { sektor }\end{array}$ & Akademici & Polisie \\
\hline $\begin{array}{l}\text { Pa begin homself skielik } \\
\text { besig hou met wapens }\end{array}$ & $31 \%(25)$ & $33 \%(14)$ & $39 \%(22)$ & $35 \%(24)$ \\
\hline Vorige selfmoordpogings & $62 \%(51)$ & $61 \%(27)$ & $61 \%(34)$ & $72 \%(50)$ \\
\hline $\begin{array}{l}\text { Onsuksesvolle pogings om } \\
\text { verbrokkelde huwelik te } \\
\text { herstel }\end{array}$ & $76 \%(62)$ & $77 \%(34)$ & $84 \%(47)$ & $91 \%(63)$ \\
\hline $\begin{array}{l}\text { Ekonomiese insinking/werk- } \\
\text { loosheid/werksverlies }\end{array}$ & $83 \%(68)$ & $77 \%(34)$ & $84 \%(47)$ & $75 \%(36)$ \\
\hline Fisieke aanranding van vrou & $55 \%(45)$ & $34 \%(26)$ & $70 \%(39)$ & $61 \%(42)$ \\
\hline Pa onttrek van gesin en bure & $44 \%(36)$ & $34 \%(15)$ & $39 \%(22)$ & $62 \%(43)$ \\
\hline
\end{tabular}

Die respondente is duidelik nie sterk oortuig van die waarskuwingswaarde van pa's wat hulle (skielik) met wapens begin besig hou nie en ook nie dat onttrekking in hierdie lig beskou moet word nie. Dit is ook merkwaardig dat die respondente nie so sterk voel oor geweld (gemiddeld 55\%) teenoor die eggenoot as 'n waarskuwing nie. Die stelling dat vorige selfmoordpogings wel in dié lig beskou moet word, het ook 'n relatief lae sterkte (64\%) van die respondente onttrek.

\section{VERKLARING}

Momberg (1989:18) sien die verklaring van gesinsmoorde as 'n refleksie van die huidige magstruktuur van die kerk en staat as 'n model wat op kleiner skaal op gesinsmoorde toegepas kan word. Hy argumenteer soos volg: Die Afrikanergesin is patriargaal en outoritêr ingestel. Mag berus by die vader. Sterk grense bestaan tussen die gesin en die gemeenskap en verandering word teengestaan. In die gesin self is interpersoonlike grense swak en die gesinslede dink en voel vir mekaar. Elkeen het nie sy eie identiteit nie. Die isolasie van die gesin met so 'n outoritêre struktuur, spieël die situasie waarin Suid-Afrika homself staatkundig in die wêreld bevind. Die resultaat is dat die gesin, soos die staat, gewelddadige en outoritêre oplossings vir probleme normaal vind en advies van buite ignoreer. As hy nie sterk genoeg is om die stress van buite te hanteer nie, sluit selfvernietiging die gesin in. 
De Jongh Van Arkel (1988:11) sluit aan by die verklaring. Volgens hom word die opvatting dat geweld onder sekere omstandighede korrek is, aangehelp deur politieke stelsels waarin minderhede vir meerderhede voorskryf. Omdat Afrikaners teen die agtergrond voel hulle kan nie die land verlaat nie en hul toekoms is onseker en word voortdurend ook herinner aan die gewelddadige omstandighede waarin ander Blankes hulself in die land bevind, kan dit gesinsmoord onder hulle verklaar.

Dit is egter nie so maklik nie (Anon 1988:12). Toe apartheid sy hoogbloei gehad het in die sestigerjare, was gesinsmoorde haas onbekend. Bloomberg (1988:22) sê ook hy twyfel of dit iets met politiek of apartheid te make het. Janson (1988:6) sê dit is nie meer so dat die Afrikaanse gesin outoritêr is nie; dit word bewys deur opnames wat gedoen is onder mense wat saamwoon. Gous (1988:6) sê die hegtheid van die Afrikaner-gesinstruktuur kan ook nie as eng beskryf word nie. Juis die gehegtheid het baie voordele wat al baie tragedies voorkom het. Bloomberg (1988:22) sê sestig persent van die wit bevolking van Suid-Afrika is Afrikaanssprekend en daarom mag dit lyk of Afrikaners meer gesinsmoorde pleeg as ander groepe.

Schmidt (1989:18) verklaar gesinsmoorde met 'n teorie oor 'n soort 'hidden executioner' wat stel dat, as die probleem te erg raak, jy nie durf voortleef nie. Hy sien dit as ' $n$ byna primitiewe voodoo-daad. Hy meen die individuasieproses is nog nie ver genoeg gevorder in sulke gesinne nie, want hulle is nog afhanklik van ander se agting vir eiewaarde. Hulle is besonder vatbaar vir gesinsmoorde, veral as daar 'n sterk presipitant is, soos wanneer daar weens finansiële probleme 'n onvermoë bestaan om verder vir die gesin te sorg. Schlebush (1989:18) het 'n verband tussen die afhanklike persoonlikheid en gesinsmoord gevind in sy navorsing. As sulke persone hulself sonder steun vind in 'n hopelose situasie, beweeg hul depressie maklik op die kontinuum van die passiewe na aggressiewe gedrag wat gesinsmoord kan insluit.

De Jongh Van Arkel bied ook 'n meer sielkundige verklaring van gesinsmoorde aan. Hy sê naamlik dit kan as uitgebreide selfmoord beskou word. Swartz (1988:9) skryf dit toe aan maniese depressie. Du Toit (1988:11) skryf gesinsmoorde toe aan die Afrikaner se houding teenoor die lewe: Hulle voel gou verneder, is geïnhibeerd, suspisieus en het sieklike selfbejammering. Roos (1988:17) se opvatting is weer dat gesinsmoorde nader is aan selfmoord as aan gesinsgeweld.

Indien die verklarings wat aangegee word, ook volgens die modale aspekte geklassifiseer word, kom die volgende aan die lig: 
Tabel 6. Literatuurstudie se lys van verklarings

\begin{tabular}{|l|l|l|}
\hline Psigologies & \multicolumn{1}{|c|}{ Sosiologies } & \multicolumn{1}{c|}{ Juridies } \\
\hline individuasie- & patriargaal en outo- & Huidige magstruktuur \\
proses word & riter; swak inter- & van die kerk en staat; \\
nie deurge- & persoonlike grense; & vitere oplossings \\
voer nie; & gesinslede dink en & advies van buite word \\
afhanklike & voel vir mekaar; & geïgnoreer; minderhede \\
persoonlik- & elk het nie sy eie & skryf vir meerderhede \\
heid; & voor \\
uitgentiteit nie; & gesin leef in iso- & \\
selfmoord & lasie; gesinstruk- & \\
& tuur is buitengewoon & \\
& heg; die Afrikaner & \\
& se lewenshouding & \\
\hline
\end{tabular}

Opmerklik is dat juridiese aspekte hier bygebring word naas die nou reeds bekende sosiale en psigiese aspekte.

Wat verklaring betref het die lede van KRIMSA die volgende na vore gebring:

Tabel 7. Respondente oor verklarings

\begin{tabular}{|l|c|l|l|l|}
\hline Verklarings & $\begin{array}{l}\text { Privaat } \\
\text { sektor }\end{array}$ & $\begin{array}{l}\text { Openbare } \\
\text { sektor }\end{array}$ & Akademici & Polisie \\
\hline $\begin{array}{l}\text { Beleef verwerping van die } \\
\text { samelewing }\end{array}$ & $62 \%(51)$ & $63 \%(27)$ & $57 \%(32)$ & $67 \%(46)$ \\
\hline Kom uit gewelddadige gesinne & $35 \%(29)$ & $40 \%(17)$ & $46 \%(26)$ & $46 \%(32)$ \\
\hline $\begin{array}{l}\text { Politieke situasie waarin } \\
\text { blankes in SA hul bevind }\end{array}$ & $12 \%(10)$ & $33 \%(14)$ & $25 \%(14)$ & $20 \%(14)$ \\
\hline 'Hidden executioner' & $30 \%(24)$ & $50 \%(21)$ & $42 \%(23)$ & $57 \%(39)$ \\
\hline Lewensfilosofie van Afrikaners & $42 \%(34)$ & $44 \%(19)$ & $42 \%(23)$ & $36 \%(25)$ \\
\hline
\end{tabular}

Die rol wat die politieke situasie in Suid-Afrika speel ten opsigte van die verklaring van gesinsmoorde, staan uit in die reaksie van die respondente. Die gemiddelde positiewe reaksie hierop is slegs $23 \%$. Dit dui daarop dat hulle glad nie sterk voel daaroor nie. Die $41 \%$ reaksies rondom die 'hidden executioner' is eweneens onver- 
wags en laag. Die feit dat gesinsmoord 'n sterk geweldskomponent besit, maak die lae $42 \%$ reaksies oor geweld in die gesin van herkoms eweneens verrassend.

\section{VOORKOMING}

Die maklikste manier om enige misdaad te voorkom, is natuurlik om die oorsake of sneilerfaktore te elimineer. Dit word ook tot op sekere hoogte in die literatuur weerspieël. Ter wille van die logisiteit van die argument wat hier gevoer word, word die voorkomingsmaatreëls onder die psigiese en sosiale modaliteite gerangskik (Van Zyl 1984:3).

Psigologiese voorkoming behoort afgestem te wees daarop om van die spanning ontslae te raak, te help met die besef dat daar 'n probleem is, en te lei om probleme met kerkleiers en huweliksvoorligters te bespreek. Sosiologiese voorkomende hulpverlening kan weer afgestem wees daarop om die werklikhede van die (ontwrigte) situasie te aanvaar (en te hanteer): Laat die polisie die vuurwapens wegneem, help met konstruktiewe lewe deur middel van hersosialisering, soek hulp by die naaste landdroskantoor en soek hulp by 'n prokureur.

Kortweg gestel kan ten opsigte van die psigiese modaliteit gesê word dat voorkoming neerkom op verligting van drukspanning en ten opsigte van die sosiale aspek kom dit weer neer op bevestiging van die geborgenheidsbehoefte.

Momberg (1988:5) sê die korttermynoplossing is daarin geleë dat mense bewus moet word van hul eie gesinstruktuur en die interaksie tussen die huweliksgenote. Hulle moet meer introspektief word en nagaan hoe hulle konflik en probleemoplossings hanteer. Op die langtermyn moet pogings aangewend word om die gesinstruktuur te verander. Die kerk, staat en die juridiese stelsel moet aan getroudes gelyke status en regte gee. Die kerk moet ook sy idee verander van hoe die gesinstruktuur moet wees. Hierbenewens moet die staat 'n goeie model voorhou van hoe probleme opgelos word deur 'n samelewing te ontwerp wat die meeste mense tevrede stel.

Naudé (1988:18) sê gesinsmoorde kan voorkom word deurdat gesinne berading moet ontvang met die eerste tekens van baie stres. Dan moet dreigimente in die verband ook nooit geïgnoreer word nie en medici moenie sommer anti-depressante voorskryf nie, maar ook pasiënte vir berading verwys as hulle depressief en moedeloos is.

De Vos (1988:7) suggereer dat voorkoming ook bevorder kan word indien daar 'n vaste struktuur bestaan waarvolgens die polisie en maatskaplike werkers kan reageer op dreigimente van gesinsmoorde. Hy sê die polisie is nie opgelei om dit te kan hanteer nie, en die maatskaplike werkers het weer nie die wetlike gesag om in te gryp om sulke mense te isoleer nie. 
Luttig (1985:6) sề in dié verband dat geen intra-gesinsprobleem te groot is dat dit nie met konstruktiewe kommunikasie opgelos kan word nie.

Francisco-la Grange (1987:6) sê die kerk se groter sensitiwiteit vir die angs van die mens kan gesinsmoorde voorkom. Sy sê die Skrif bied in 'n sekere sin 'n uitnodiging tot die dood omdat Christus dit oorwin het. Tog moet die dood nie voorgehou word as die oplossing van die mens se probleme nie, want God beskik daaroor. Buitendien wys sy ook op die feit dat die mens reeds hier op aarde genade en vergifnis van sonde kan ontvang. De Jongh Van Arkel (1987:6) sluit ook hierby aan en sè die kerk sal moet nagaan of hy so ' $n$ rol speel dat 'n soort omgewing daargestel word waarbinne 'n gesinsmoord moeilik sal kan plaasvind.

Modaal geherrangskik, kom die voorkomingsaksies (gereduseerd) wat deurgegee word, op die volgende neer:

Tabel 8. Literatuurstudie oor voorkoming

\begin{tabular}{|l|l|l|l|}
\hline \multicolumn{1}{|c|}{ Psigologies } & Sosiologies & Juridies & Godsdienstig \\
\hline $\begin{array}{l}\text { Berading met } \\
\text { eerste tekens } \\
\text { van stess }\end{array}$ & $\begin{array}{l}\text { Soek dadelik } \\
\text { hulp as ge- } \\
\text { sinsmoord } \\
\text { oorweeg word }\end{array}$ & $\begin{array}{l}\text { Verander die } \\
\text { staatkundige } \\
\text { bestel }\end{array}$ & $\begin{array}{l}\text { Kerk ontwikkel } \\
\text { groter sensi- } \\
\text { tiwiteit vir die } \\
\text { angs van die mens }\end{array}$ \\
\hline
\end{tabular}

Ten opsigte van voorkoming word die sosiale, psigiese, juridiese en godsdienstige modale aspekte dus deur die aangehaalde akademici benoem.

Betreffende voorkoming het die respondente baie sterk opinies uitgespreek. Dit word in tabel 9 weergegee:

Tabel 9. Respondente oor voorkoming

\begin{tabular}{|l|l|l|l|l|}
\hline \multicolumn{1}{|c|}{$\begin{array}{l}\text { Voorkomings- } \\
\text { aksies }\end{array}$} & $\begin{array}{c}\text { Privaat } \\
\text { sektor }\end{array}$ & $\begin{array}{l}\text { Openbare } \\
\text { sektor }\end{array}$ & Akademici & Polisie \\
\hline Hanteer stress effektief & $92 \%(75)$ & $92 \%(39)$ & $95 \%(53)$ & $94 \%(64)$ \\
\hline Erken en bespreek probleme & $85 \%(70)$ & $83 \%(35)$ & $88 \%(49)$ & $91 \%(63)$ \\
\hline $\begin{array}{l}\text { Aanleer van konstruktiewer } \\
\text { lewenswyse }\end{array}$ & $87 \%(71)$ & $93 \%(40)$ & $84 \%(47)$ & $90 \%(62)$ \\
\hline $\begin{array}{l}\text { Herstel bestaande versteurde } \\
\text { gesinsverhoudinge }\end{array}$ & $90 \%(74)$ & $88 \%(38)$ & $89(50)$ & $94 \%(65)$ \\
\hline
\end{tabular}


Uit die gegewens van tabel 9 kan duidelik afgelei word dat die respondente die uitsprake van die literatuur sterk ondersteun as dit kom by die wyses waarop gesinsmoorde voorkom kan word.

\section{SLOTBESKOUING}

Saamgevat kan die bevindinge oor die oorsake, waaskuwingstekens, verklarings en voorkoming van gesinsmoorde, soos dit in hierdie navorsing na vore gekom het, soos volg geskematiseer word:

Tabel 10. Bevindinge oor gesinsmoorde

\begin{tabular}{|c|c|}
\hline \multicolumn{2}{|c|}{ Oorsake } \\
\hline $\begin{array}{l}\quad \text { Psigologies } \\
\text { Gevoelens van verwerping } \\
\text { Erge stress } \\
\text { Emosionele uitbranding } \\
\text { Patologiese besitlikheid }\end{array}$ & $\begin{array}{l}\quad \text { Sosiologies } \\
\text { Vervreemding tussen man en vrou } \\
\text { Misbruik van sterk drank }\end{array}$ \\
\hline \multicolumn{2}{|c|}{ Waarskuwingstekens } \\
\hline $\begin{array}{c}\text { Psigologies } \\
\text { Vorige selfmoordpogings }\end{array}$ & $\begin{array}{l}\quad \text { Sosiologies } \\
\text { Pa begin homself skielik met } \\
\text { wapens besig hou } \\
\text { Onsuksesvolle pogings om die } \\
\text { verbrokkelde huweliksverhouding } \\
\text { te herstel } \\
\text { Ekonomiese insinking/werkloosheid } \\
\text { werksverlies } \\
\text { Fisieke aanranding van vrou } \\
\text { Pa onttrek van gesin en bure }\end{array}$ \\
\hline \multicolumn{2}{|c|}{$\begin{array}{c}\text { Verklarings } \\
\text { Sosiologies } \\
\text { Beleef verwerping van die samelewing }\end{array}$} \\
\hline \multicolumn{2}{|c|}{ Voorkoming } \\
\hline $\begin{array}{l}\quad \text { Psigologies } \\
\text { Hanteer stress effektief } \\
\text { Erken en bespreek } \\
\text { probleme }\end{array}$ & $\begin{array}{l}\quad \text { Sosiologies } \\
\text { Aanleer van konstruktiewe lewenswyse } \\
\text { Herstel bestaande versteurde } \\
\text { gesinsverhoudinge }\end{array}$ \\
\hline
\end{tabular}


Uit hierdie samevattende diagram kan, wat die hipotese van die navorsing betref, afgelei word dat dit duidelik is dat dit breedweg ondersteun word: Die ingeligtes ondersteun die meeste van die stellings wat in die navorsing getoets is. Die lede van die Kriminologiese Vereniging van Suider Afrika stem breedweg saam oor die oorsake, waarskuwingstekens, verklarings en voorkoming van gesinsmoorde, afgesien van die beroepsareas waarin hulle werksaam is. Dit word veral gedoen in terme van die psigologiese en sosiologiese aspekte. Die respondente is nie geneë om sterk saam te stem daarmee dat juridiese, seksuele, ekonomiese en godsdienstige aspekte betekenisvolle bydraes makk tot die wetenskaplike begrip van die verskynsel nie. Die literatuurstudie het uitgewys dat verskillende (vak)wetenskaplikes die verskynsel van gesinsmoorde reduseer tot hierdie inspelende faktore. Vir sover as wat die lede van KRIMSA slegs daaroor ondervra is, stem hulle breedweg saam. Daarmee kom die holistiese verstaan van die verskynsel ietwat in die gedrang. Van der Walt (1982) en ander het immers aangetoon dat menslike gedrag verstaan moet word in terme van meer as slegs hierdie (modale) aspekte. Dit wil ook voorkom asof die politieke modaliteit kunsmatig ingevoer word. Verdere navorsing oor hierdie verskynsel kan dalk nuttig gebruik maak van die bevindinge van tabel 10 om as 'n soort van merklys te dien vir verdere in diepte navorsing.

Indien ons egter ernstig is om in Suid-Afrika 'n duik te slaan in gesinsmoorde, moet ons ernstig daaraan aandag gee om die wetlike bevoegdhede van maatskaplike werkers, kliniese sielkundiges, psigiaters en ander in die hulpverlenende professies, uit te brei. Die probleem hiermee is natuurlik dat 'n verantwoordelike wetenskaplike voorspeller(s) ontwerp sal moet word wat minstens 'n aanduiding kan gee van die risikograad vir die voorkoms van die misdaadsoort. So 'n uitdaging behoort egter nie 'n verleentheid vir die toegewyde vakwetenskaplikes in die laaste dekade van die twintigste eeu te wees nie.

\section{Literatuurverwysings}

Anoniem 1988. Agt sterf in twee gesinsmoorde. Die Bunger 23 Junie, 1.

Bachar, A 1985. Seks, geld en drank by grootste oorsaak van gesinsmoorde. Die Vaderland 17 Januarie, 6.

Bloomberg, S 1988. Gesinsmoord; Afrikaner sindroom? Rooi Rose 17 Augustus, 22. De Jongh Van Arkel, J 1988. Gesinsmoorde: 'n Toenemende verskynsel. Unisa Bulletin 13/4, 11.

De Vos, A 1988. Gesinsmoord; 'n Siekte van die Afrikaner. Beeld 23 Junie, 9.

Du Toit, F 1988. Power link in family murders, says prof. The Star 14 June, 15.

Erasmus, J A K 1988. Murderous loss of a love object. Pretoria News 23 June, 18. 
Francisco-la Grange, F 1987. Gesinsjaar 1987 - ook 'n jaar van gesinsmoorde. Die Kerkbode 46/14, 6.

Gous, A 1988. Kerk voorkom sulke dade. Die Vaderland 8 Augustus, 6.

Janson, M 1988. Kerk voorkom sulke dade. Die Vaderland 8 Augustus, 6.

Luttig, B 1985. Most family killings are among white Afrikaners. Reported by K. O'Reilly. The Star 22nd March, 6.

Momberg, D 1988. Farther power gets blame for murders. Weekend Argus 17 September, 5 .

--- 1989. Gesinsmoord: almal moet omgee. Insig Februarie, 1, 18.

Naude, B 1988. Family murders: Expert study necessary. Pretoria News 18 August, 16.

Olivier, L 1988. Family murder as a socio-psychological phenomenon in the Republic of South Africa. South African Joumal of Sociology 19/3, 117-119.

Pienaar, P J J 1978. Gesinsmoord; 'n kommerwekkende verskynsel. Woord en daad 19/195, 16-18.

Roos, L 1988. Gesinsmoord; hoe lyk die man wat so-iets beplan? Die Huisgenoot 23 Junie, 21.

Schmidt, C 1989. Gesinsmoord: Almal moet omgee. Insig Februarie, 1, 18.

Swartz, F 1988. Gesinsmoord; 'n siekte van die Afrikaner. Beeld 23 Junie, 9.

Van Zyl, J 1984. Vaders moor gesinne uit wanhoop. Die Beeld 20 November, 3. 